\title{
hoje tem fumus boni iuris em chã: as vantagens de ser fluvial RESENHA DE CHÃ (2018), DE ENOO MIRANDA
}

\section{Vinicius Gomes Pascoal ${ }^{1}$}

A menor distância entre quaisquer dois pontos é um poeta. Neste breve texto resiste uma tentativa de demonstrar como o poeta Enoo [Vinicius Bastista de] Miranda utiliza a metáfora do rio para a escrita de sua obra, Chã (2018).

Para tal efeito, utiliza-se enoo enquanto trocadilho etimológico existente no nome do autor de Chã. O rio Enns dá origem ao nome Enoo, em língua portuguesa. Esse rio nasce a 1.800 pés acima do mar. Se espalha por 518 mil metros de caminhada. Nasce pelo oeste Suíço de são Maurício. Passa imigrante pela Áustria. E por fim, chega na Alemanha.

Nesse trajeto de refugiado a única certeza é que a água sempre encontrará um caminho. É a descoberta de saber por onde a vida vai continuar.

A chave de leitura de Chã acontece pela compreensão da Zona da Mata Norte pernambucana. A cidade de Nazaré da Mata tem um décimo da extensão total do rio Enns que inspira o fluxo deste livro de poema. Na rota de aproximadamente $65 \mathrm{~km}$ entre Recife e a Zona da Mata Norte, enquanto participante das sessões do Cineclube Azouganda e dos afetos vespertinos à sombra e calmaria do Espaço Mauro Mota entre 2009 e 2013, o escritor pesquisou a fúria sertaneja de Faulkner e Guimarães Rosa muito antes do advento Bacurau tomar os círculos de conversa. Hoje, o autor coordena o Cineclube Tela da Mata em paralelo às atividades de docência e produção cultural da cadeia do Livro Leitura Literatura e Bibliotecas por trás da aparelhagem de maçã retroiluminada por Steve Jobs e Tim Cook.

Pelas páginas de Chã o leitor vai encontrar um Enoo Flegetonte, que em águas flamejantes caminha pelas profundezas de Nazaré da Mata,

1 Mestre em Teoria da Literatura pela UFPE (2015). Atualmente é tradutor freelancer na APPEN, pesquisador no NELI-UFPE \&WYDEN, além de professor convidado no Programa de Pós-graduação em língua inglesa da Universidade de Pernambuco - UPE e no Programa de Pós-graduação em Literatura da Faculdade Frassinetti do Recife - FAFIRE. E-mail: vinicius.pascoal@icloud.com 
Paudalho, Itambé, Goiana, e por onde mais se espalhar a BR 408. Essa correnteza dos versos vai lentamente, página por página, punindo e cozinhando em sangue fervente aqueles que cometeram crimes de violência contra seus pares. Assassinos, tiranos, capatazes, milicianos, empreiteiros, cimenteiros, políticos, vigilantes de usineiros, senhores de engenho com suas arquiteturas patronais de privilégios e trocas de favores. Todos esses vão sendo afogados nominalmente, ficando submersos na profundeza de violência e sofrimento que causaram.

\author{
INALAÇÃO \\ labaredas mascam \\ as margens da BR 408 \\ e o fogo fura a cor do céu \\ em brasa \\ lusco-fosco \\ pós-apocalíptico
}

quisera fosse solstício de inverno

dia de São João Batista

sobrenome do meu avô

e as águas do Jordão jorrassem

sem parar

para lavar os pés

de que lavra o eito

desde tenro leito

e devorar cabeças

de capatazes em motocicletas

que ainda não foram

decapitados

pela jihad raivosa

de pomposos califas caminhando

sobre o mármore negro de fuligem

enquanto o panteão incendiário da mata 
assiste Vishnu adormecer

no seio de Zumbi.

MIRANDA (2018, p. 38-39).

De versos amolados, Chã apresenta um Enoo Lete \& Estige de hipertrofia muscular às causas sociais e sobretudo leitor dos versos de Mauro Mota e de Oscar Brandão da Rocha, seus conterrâneos da literatura. Nesses versos honrados do mundo idílico transbordam a alegria e afetividade que pululam as questões cotidianas da Zona da Mata Norte. Supõe-se nesta resenha que tais diálogos sejam fruto de uma provável sinergia do combate entre os versos de Mota, de Brandão de Rocha e dos versos contidos em Chã, como se perguntassem:

- De onde vem essa chuva trazida na ventania?

- Que rosas fez abrir? Que cabelos molhou?

- Deus te salve, princesa da Mata, com teus campos virentes em flor; Nossas almas cantando, arrebata, manda dos céus nossos cantos de amor.

Para um momento de contemplação coletiva que mais parece um encontro das águas ácidas do texto com um oceano cheio de "Perfume":

\section{[...] sem vandalismo é o caralho \\ e é provável que belzebu \\ tenha tatuado no peito \\ durante uma sessão da Universal: \\ gentileza gera gentileza}

Mais amor por favor é pixo-poemeto

de elite branca alternativa

que nunca

levou baculejo

da polícia militar

o caminho

é mais ódio

sem pedir licença

e tem ódio aqui em 


\author{
cada esquina \\ do país em que \\ pinho sol é \\ artefato bélico \\ ao sol a pino, \\ ativista vira \\ terrorista e Activia \\ virá \\ a \\ ser \\ café da manhã. \\ MIRANDA (2018, p. 45).
}

Essa doçura hipnotizante do mel de engenho, das rapaduras, do alfenim e canaviais da economia sucroalcooleira deve ser muy acolhedora nas Torres e Casas e Fortes do Pernambuco holandês escravagista, ou quem sabe talvez, em sua versão recheada de reformas neoliberais do capital financeiro contemplado por arranha-céus na Zona Sul. Esse gosto da Mata Norte também estoura os carburadores dos veículos que carrega trabalho humano em forma de gado para o poeta conjurar enquanto "transfusão off road de vermelho sangue em etanol" (MIRANDA, 2018, p.40).

Quando a essência de um Enoo, a forma da água, decide parar sua jornada, então se autoproclama aquífero. É sinalizado o desejo de ficar, para armazenar, reter, ceder, e um dia quem sabe partir. Nesse sentido, Chã parece um aquífero Guarani. Quando um Enoo decide seguir, logo se autoproclama Enoo Alísios. Diferente de um sufrágio universal, ao poeta a autodeclaração é a diplomação de sua chefia executiva estética, devendo assumir a missão de flutuar e provocar chuvas enquanto sopra de nordeste a sudoeste.

Esse brevíssimo apontamento que alcança leitores e leitoras pede permuta da função de leito para tornar-se margem esquerda do Enoo Tracunhaém que andou sobre o corpo pelo córrego Morojó, pelos Karamázov, Pacha Mama, pela imagem em movimento em Trainspotting, ou perto da escolha tropical feita por Bela Lugosi para gozar sua aposentadoria vampírica; Ainda sobre as vantagens de ser corrente fluvial, resta-nos outrora visita em Tel Aviv em busca de Tony Blair e quem sabe uma contaminação por ebola. 
Quem se dedicou ao estudo de Faulkner e Rosa sabe que o Enoo Missisipi só se esgota depois de passar por três níveis: o alto, o médio e o baixo. O caminho desse poeta flutuante, sem credenciamento nos círculos armoriais, listas de influências, academicismos, clubes recreativos de escrita criativa ou passaporte oriundo de um sacro Pernambuco edificado em legado e laços sanguíneos, imprime a possibilidade de um caminhar sem tempo.

O rio de Enoo Miranda se chama Chã, e carrega consigo as vozes, lutas e memórias de um povo que insiste em se rebelar. São essas rebeldias que aclamam a obra enquanto vencedora do $5^{\circ}$ prêmio Pernambuco de Literatura $^{2}$ e publicado pela CEPE - Companhia Editora de Pernambuco. Outras produções do escritor também podem ser encontradas em Inquebrável: Estelita pra cima (2014) e Coletânea 1 (2015), da Mariposa Cartonera e Livrinho de Papel Finíssimo, respectivamente.

\section{referências}

MIRANDA, Enoo. Chã. Recife: CEPE, 2018.

. Inquebrável: Estelita para cima. Recife: Mariposa Cartonera, 2014. . Coletânea 1. Recife: Livrinho de Papel finíssimo, 2015.

2 Em sua VI edição o Prêmio Pernambuco de Literatura foi renomeado para Prêmio Hermilo Borba Filho de Literatura. 